\title{
PENINGKATAN PERAN KOHESI DAN SOLIDARITAS SOSIAL PETANI MENDUKUNG KEBERHASILAN PENYALURAN JARING PENGAMAN SOSIAL DI MASA PANDEMI COVID-19
}

\author{
IMPROVING THE ROLE OF COHESION AND FARMERS 'SOCIAL SOLIDARITY \\ TO SUPPORT THE SUCCESSFUL DISTRIBUTION OF SOCIAL SAFETY \\ NETWORKS IN THE COVID-19 PANDEMIC TIME
}

\author{
Roosganda Elizabeth \\ Pusat Sosial Ekonomi dan Kebijakan Pertanian, Kementerian Pertanian \\ Email: roosimanru@yahoo.com \\ (Diterima 29-12-2020; Disetujui 14-1-2021)
}

\begin{abstract}
ABSTRAK
Wabah pandemi Covid-19 yang cepat dan meluas penyebarannya di seluruh penjuru dunia dan masih berlangsung, sangatlah mempengaruhi perekonomian masyarakat dan kehidupan di seluruh negara. Dampaknya terhadap kehidupan ekonomi-sosial masyarakat dan negara, diantaranya meningkatnya pengangguran dan kesulitan ekonomi. Ketiadaan penghasilan akibat terputus/hilangnya sumber mata pencaharian untuk memenuhi kebutuhan pangan sandang menjadi pilar penting. Selain sektor perekonomian dan kesehatan, juga mempengaruhi sektor pertanian dan yang terkait dengannya. Tulisan ini bertujuan untuk mengemukakan peran aktif pemerintah dalam menanggulangi kesulitan ekonomi dan sektor pertanian melalui penyaluran program bantuan Jaring Pengaman Sosial (JPS) yang lebih tepat sasaran, jenis bantuan dan waktu penerimaannya. Dengan metode deskriptif kualitatif diuraikan review berbagai informasi, literatur dan hasil kajian terkait penyaluran JPS khususnya terhadap petani kecil di masa pandemi Covid-19. Berbagai situasi dan kondisi masyarakat dan dunia cenderung mencerminkan terjadinya kepanikan tidak saja pada sendi kesehatan, tetapi juga meluas hingga tatanan perekonomian, keamanan pangan dan kehidupan sosial yang membutuhkan penanganan yang lebih serius. Pandemi Covid-19 merupakan suatu momentum telah membawa berbagai dampak yang luas dan multi dimensi, dimana mekanisme normal yang mengandalkan mekanisme pasar sulit untuk melakukan recovery. Perlunya memberdayakan dan meningkatkan kohesi dan solidaritas sosial yang sangat penting dalam menjaga kohesi antar warga dan menjadi alat kontrol sosial, disertai nilai-nilai altruisme yang tumbuh dan berkembang selama ini di masyarakat harus dihidupkan kembali sebagai solidaritas sosial yang dapat memperkuat kohesi sosial masyarakat. Program JPS merupakan keniscayaan yang harus dijalankan pemerintah, meski disertai intervesi dalam kelancaran pelaksanaan penyalurannya.
\end{abstract}

Kata Kunci: petani kecil, rentan, jaring pengaman sosial, kohesi sosial, solidaritas social

\begin{abstract}
The Covid-19 pandemic outbreak, which is fast and widespread, has spread throughout the world and is still ongoing, greatly affecting the economy of people and life in all countries. The impact on the socio-economic life of society and the country, including increased unemployment and economic hardship. The absence of income due to disconnection / loss of livelihood sources to meet food and clothing needs is an important pillar. Apart from the economic and health sectors, it also affects the agricultural sector and related to it. This paper aims to present the active role of the government in overcoming economic difficulties and the agricultural sector through the distribution of the Social Safety Net (SSN/JPS) assistance program which is more targeted, the type of assistance and the timing of its receipt. With the qualitative descriptive method, a review of various information, literature and results of studies related to the distribution of JPS especially to small farmers during the Covid-19 pandemic is described. Various situations and conditions in society
\end{abstract}


and the world tend to reflect panic not only in health, but also extending to the economic structure food security and social life which require more serious handling. The Covid-19 pandemic is a momentum that has brought various broad and multi-dimensional impacts, where normal mechanisms that rely on market mechanisms are difficult to recover. The need to empower and increase social cohesion and solidarity which are very important in maintaining cohesion between citizens and being a means of social control, accompanied by the values of altruism that have grown and developed in society must be revived as social solidarity that can strengthen social cohesion. The JPS program is a necessity that must be carried out by the government, even though it is accompanied by interventions in the smooth implementation of its distribution.

Keywords: small farmers, vulnerable, social safety net, social cohesion, social solidarity

\section{PENDAHULUAN}

Wabah COVID-19 yang

disebabkan virus corona SARS-CoV-2 menyebabkan situasi dan kondisi yang serba tidak menentu (kepanikan). Di masa pandemi Covid-19, pertahanan keamanan pangan, ketahanan dan tatanan kehidupan sosial membutuhkan perhatian yang lebih serius. Permasalahannya bukan hanya banyaknya orang terpapar, melainkan dampaknya terhadap kehidupan ekonomi-sosial masyarakat dan negara, diantaranya meningkatnya pengangguran dan kesulitan ekonomi. Ketiadaan penghasilan akibat terputus/hilangnya sumber mata pencaharian untuk memenuhi kebutuhan pangan sandang menjadi pilar penting. Pemerintah dalam penanganan COVID19, menyatakan bahwa episentrum sebelumnya berpusat di daerah perkotaan, kini terus menyebar ke daerah lain dan dikhawatirkan menjadi episentrum baru.
Pandemi Covid-19 telah membawa berbagai dampak yang luas dan multi dimensi, sehingga mekanismemekanisme normal yang misalnya mengandalkan mekanisme pasar sulit untuk melakukan recovery. Di masa sulit dan terdampak akibat wabah pandemi Covid-19, mengimplikasikan berperannya program kebijakan bantuan yang salah satunya adalah Jaring Pengaman Sosial (JPS). Urgensi, kebutuhan dan efektifitas penyaluran JPS didasari pemahaman dasarnya suatu analogi dimana berlanjutnya kehidupan dengan semestinya, bila ada sumber penghasilan (termasuk bantuan) yang dapat dan siap menopang dan menyokong keberlanjutan penghidupan terutama di kondisi dan situasi tidak berpenghasilan. Pemberian bantuan dan dukungan untuk petani dan keluarga serta pelaku pertanian lain perlu dilakukan secara tepat agar efektif. Dampak Pandemi Covid-19 bagi petani kecil terkait 
perannya sebagai produsen sekaligus konsumen yang penanganannya yang dapat bermanfaat langsung bagi kelanjutan kehidupan keluarga, usahatani dan komunitasnya (individu level impact dan population/community-level impact).

Berbagai upaya teknis, sosial dan ekonomis dalam mengatasi pandemi Covid-19 juga harus didukung dengan penguatan sosial ekonomi semua lapisan masyarakat (terutama petani kecil). Petani kecil (dan masyarakat golongan menengah ke bawah) adalah kaum rentan karena berbagai keterbatasannya. Dengan JPS sebagai salah satu program kebijakan bantuan yang bergerak di aras sosial dan lebih mengarah ke ranah bantuan ekonomi (modal usaha/kerja), merupakan upaya pemerintah dalam mengatasinya. Pemahaman dasarnya merupakan suatu analogi yang membantu ketika kondisi sulit si penerima supaya keberlanjutan penghidupannya dapat berjalan dengan baik. JPS bukan bantuan untuk bangkit kembali, tapi sokongan pencegahan sebelum mati karena tidak mampu lagi memenuhi kebutuhan hidup. Pelaksanaan penyaluran JPS ditengarai dapat terpelihara dengan kohesi dan solidaritas sosial dan publik, dan dioptimalkan sampai ke masyarakat lapisan bawah.

Dengan penguatan kohesi dan solidaritas sosial, setiap warga negara jadi memiliki kesadaran, kepedulian, dan kepercayaan, baik pada pemerintah maupun antar masyarakat, guna mendukung keberhasilan program pemerintah dalam mengatasi berbagai kesulitan di masa pandemi Covid-19. Tulisan ini secara metode deskriptif kualitatif mengemukakan dengan lebih komprehensif kebutuhan kaum/golongan yang terdampak terhadap program JPS untuk menghadapi tekanan pandemi Covid-19, khususnya petani kecil dan masyarakat menengah ke bawah yang rentan; efektivitas JPS sebagai program penanganan pandemi Covid-19; peran dan kebutuhan terhadap program JPS; prospek dan efektivitas penerapan JPS di masa pandemi Covid-19; perubahan sosial di masa Covid-19. Dengan demikian, program JPS merupakan keniscayaan yang harus dijalankan pemerintah, meski disertai intervensi demi kelancaran implementasinya.

\section{METODE PENELITIAN}

Berbagai upaya secara simultan dilakukan pemerintah dan masyarakat untuk mengatasi berbagai situasi, 
masalah dan kendala yang dihadapi semua lapisan masyarakat terutama petani kecil dan golongan menengah ke bawah yang rentan terdampak pandemi Covid-19. Secara deskriptif kualitatif tulisan ini bertujuan mengemukakan akselerasi penyaluran jaring pengaman sosial medukung pengentasan kerentanan petani kecil dan terjadinya perubahan sosial di masa pandemi Covid-19. Untuk memperkaya cakupan tulisan, dilakukan review berbagai data informasi dan literatur terkait meliputi: apa itu petani kecil, apa dan bagaimana urgensi dan kebutuhan petani kecil, dan masyarakat yang rentan terdampak terhadap program JPS, terkait: efektivitas dan prospek penerapan program JPS di masa pandemi Covid-19, serta perubahan sosial di masa Covid-19. JPS merupakan salah satu dari berbagai program kebijakan bantuan yang dicanangkan pemerintah terhadap para korban yang terdampak kesulitan. JPS merupakan bantuan non-kontribusi yang di sektor pertanian adalah untuk meningkatkan kehidupan petani kecil yang rentan karena berbagai keterbatasannya.

\section{HASIL DAN PEMBAHASAN}

Penyebaran Covid-19 (disebabkan virus Corona SARS-CoV-2) semakin luas, baik secara global dan nasional sudah di tingkat pandemi karena begitu cepat dan masif. WHO (11/3/2020) menyatakan sebagai bencana non-alam global. Terkait dengan Undang-undang Nomor 24 Tahun 2007 tentang Penanggulangan Bencana, yang membagi bencana menjadi bencana alam, nonalam, dan sosial, terbit Keputusan Presiden Nomor 12 Tahun 2020 tentang Penetapan Wabah Pandemi Covid-19 sebagai Bencana Non-alam Nasional. Bencana non-alam adalah bencana yang diakibatkan oleh peristiwa atau rangkaian peristiwa nonalam yang antara lain berupa gagal teknologi, gagal modernisasi, epidemi, dan wabah penyakit (BPS, 2020).

Sejak pemerintah pertama kali mengkonfirmasi wabah Covid-19 tanggal 2 Maret 2020, kasus orang terpapar dan meninggal terus bertambah dan meningkat secara signifikan dan sudah menyebar di 32 provinsi dari total 34 provinsi di Indonesia, meski jumlah korban yang sembuh juga meningkat. Peningkatan yang terpapar secara eksponensial menunjukkan bahwa belum terjadinya kurva pelandaian seperti pernah diprediksi, yang mengindikasikan bahwa pandemi Covid-19 tidak bisa disikapi secara permisif. Perlunya 
dilakukan langkah sistematis, terukur, dan komprehensif dalam aspek penanganannya. Petani kecil, masyarakat miskin, kaum rentan, dan yang bekerja di sektor informal merupakan yang paling terdampak dari mewabahnya pandemi Covid-19.

URGENSI JPS BAGI PETANI KECIL SEBAGAI KAUM RENTAN

Pengertian Petani, Esensi dan Karakteristik Petani Kecil

Dalam berbagai literatur, dikenal konsep umum petani (farmer) sebagai pelaku usahatani sebagai sumber matapencahariannya. $\mathrm{Di}$ Indonesia (dokumen resmi) tidak dikenal petani besar dan petani kecil petani, tetapi pembedaan atas komoditas yang diusahakan. Pembedaan atas petani pangan, petani kebun, peternak, dan seterusnya, tidak berkaitan dengan atribut sosial ekonomi dan politiknya, yang bertujuan memudahkan pemerintah untuk menentukan sasaran dan kegiatan program kebijakan pembangunan pertanian. Menurut IAASTD (International Assessment of Agricultural Knowledge, Science \& Technology for Development; WHO. 2008) adalah karena pemerintah seringkali terlupa (keliru) dalam mengurus sektor pertanian skala kecil dan petani kecil, menjadi akar terdalam krisis pangan.

Peasant (subsistence farmer) merupakan petani yang sesungguhnya, yang dalam kesehariannya mengerjakan sendiri setiap tahapan usahatani (mengolah tanah hingga panen), meskipun berada pada level bawah (Tjondronegoro. 1984; 1999; Trijono. 1994). Bagi petani yang hanya menyediakan tenaga kerja disebut dengan farmhands, growers sebagai buruh tanpa lahan, dan sharecroppers atau sharefarmers adalah para petani penyakap (Mc.Koen. 1990; Monbiot. 2008). Small farmer adalah petani berlahan sempit (smallholder), tenant farmer (penyakap), atau peasant, dengan jenis petani lain misalnya entrepreneurial and large scale corporate (Unal. 2005; Hazel. 2006; Chappel. 2011). Peasant dan farmer memiliki perbedaan konotasi dan atribut, dimana peasant gambaran petani subsisten (petani kecil), penyewa (tenants), penyakap (sharecroppers), dan buruh tani, sedangkan farmer adalah petani modern bertujuan agribisnis yang menerapkan teknologi modern berbasis jiwa bisnis (Harvest. 2002; Soekartawi; Mubyarto. 2003 dalam Elizabeth. 2017; 2019). 
Keberadaan petani kecil ini semakin penting bagi dunia. Pertanian skala kecil lebih mampu beradaptasi dan pejal, sekaligus model keberlanjutan yang ramah kearifan lokal dan keragaman hayati, termasuk untuk menghadapi perubahan iklim (Aier. 1995; Altieri. 1995; Altieri, 2008; dalam Santoso. 2011; 2012). Berbagai hasil riset menunjukkan pertanian kecil jauh lebih produktif dari pertanian industrial karena mengonsumsi sedikit input terutama bahan bakar minyak (Rosset, 1999 dalam Elizabeth. 2017; 2017a). Ciri umum peasant adalah sikap kerjasama antar peasant, usahatani skala kecil, menggunakan tenaga kerja dalam keluarga, mengutamakan pemenuhan konsumsi sendiri. Karena berskala kecil (small scale) dan lebih intensif, lahan ditanami berbagai tanaman/tumpangsari (intercropping), dan sudah mulai penanaman tanaman baru sebelum panen selesai. IP lahan bisa lebih dari 500 persen dalam setahun, terutama pada usahatani palawija dan hortikultura (Trijono. 1994; Stefan, 1997 dalam Syahyuti. 2012).

Oleh karena itu, memperhatikan pertanian skala kecil tidak hanya memberi pangan dunia, tetapi juga menyelesaikan kemiskinan dan kelaparan
(Amaludin. 1997). IAASTD (WHO, 2008) menyimpulkan bahwa model pertanian ekspor-industrial-monokultur bukan mengatasi kemiskinan dan kelaparan, malah merusak lingkungan (air dan tanah), menggerus keanekaragaman hayati dan kearifan lokal (olah tanah, pola dan waktu tanam, pengendalian HPT), dan menyebabkan kerentanan. Petani harus dipahami dalam konteks sebagai individu, keluarga dan komunitas, karena di masa pandemi Covid-19 memiliki dampak berbeda pada ketiga level tersebut, yang akan berbeda pula dalam menyusun strategi penanggulangan dampaknya. Sedangkan dari sisi komunitas, petani diorganisasikan dalam garis keorganisasian wilayah (dusun, kampung dan desa); dan juga keorganisasian formal petani (kelompok tani, gapoktan, d11) (Syahyuti. 2013; Elizabeth. 2019).

Dalam pengertian tehnis, produksi berarti proses memadu (menggunakan) faktor-faktor produksi untuk menghasilkan sesuatu (produk usahatani). Dalam pengertian ekonomis, produksi berarti pekerjaan yang menghasilkan/berguna/kegunaan, memperbesar guna tersebut dan membagikan kepada orang banyak. Petani dalam melakukan proses produksi 
secara teknis didasarkan kemampuannya menggunakan faktor-faktor produksi dengan segala usaha/ tindakan sehingga diperoleh/menghasilkan produk bernilai ekonomis dan berguna bagi dirinya dan orang lain. Secara komersil, suatu proses produksi sebagai usaha/kerja yang bertujuan memperoleh pendapatan/keuntungan sebesar-besarnya dengan mengefektifkan pengalokasian sumber-sumber produksi yang dikuasai, supaya diperoleh pendapatan maksimum.

\section{Urgensi JPS bagi Petani Kecil di Masa}

\section{Covid-19}

Pemahaman umum petani tentang COVID-19 adalah penyakit pernafasan dengan gejala berupa batuk berat, flu, cepat menyebar dan bahkan dapat menyebabkan kematian, namun masih ada petani di pelosok belum tahu tentang COVID-19. Terjadinya perubahan perilaku petani (92\%) dengan melakukan protokol kesehatan: cuci tangan, memakai masker dan menjaga jarak. Ada lima tantangan utama yang dihadapi petani di masa pandemi mencakup keseluruhan sistem produksi sampai distribusi dan konsumsi, agar layak hidup yang baik, yaitu: (i) tenagakerja upahan terbatas dan mahal; (ii) pupuk subsidi terbatas; (iii) akses informasi terbatas; (iv) kesulitan penjualan hasil pertanian; (v) turunnya harga komoditas. Mengurangi orang berkumpul maka kegiatan kelompok tani sudah jarang diadakan, beberapa diskusi dilakukan melalui WhatsApp group. Terganggunya memperoleh informasi pertanian karena petugas lapang dan penyuluh dari perusahaan swasta tidak lagi mengunjungi desa mereka. Mengurangi frekuensi keluar rumah, maka waktu membeli input dan menjual hasil panen berkurang. Perubahan modal pertanian karena kenaikan harga input pertanian sekitar 10\%-75\% (pupuk naik Rp1500/kg, pestisida naik Rp5000-8000/paket di Purworejo, JaTeng; benih padi naik dari $\mathrm{Rp} 15000 / \mathrm{kg}$ menjadi Rp25000/kg di Lombok Tengah, NTB; buruh tani naik menjadi Rp100.000/hari di Lombok Timur, NTB).

Terhambatnya beberapa distribusi pupuk subsidi (Ponska dan SP36) ke desa, namun tidaklah sulit bagi beberapa petani yang biasa menggunakan benih retain dan kompos. Beberapa petani tidak/mengurangi jasa buruh tani luar lokasi terkait resiko penularan, sehingga waktu kerja dan panen menjadi lebih lama karena tidak serentak dilakukan. Petani beralih menggunakan mekanisasi (alsintan) dan berbagi dengan petani lain. 
Selain faktor cuaca dan ketersediaan air beberapa perubahan jadwal tanam mulai terjadi, perubahan permintaan pasar akan merubah komoditas dan rotasi tanam yang cepat untuk menghasilkan uang, perubahan luas tanam sekitar $25 \%-50 \%$. Petani merasa harga komoditas padi, jagung, cabai dan sayur-mayur turun kecuali bawang merah, dan kegiatan penjualan terganggu karena PSBB pasar sudah mulai tutup, petani mencari pasar lain sambil menunggu panen. Petani menggunakan Internet (Google dan Youtube) untuk mendapatkan informasi pertanian (membeli dan menjual produk pertanian) dan aktifitas keseharian lainnya.

Agenda penting yang dapat dijalankan sebagai instrumen penanggulangan dampak, yaitu: (1) mencegah dampak utamanya pada kesehatan dan produksi pangan; dan (2) strategi penanggulangan ke depan yang mencakup proses pemulihan dan akselerasi. Di masa pandemi Covid-19, dampak yang dirasakan petani berkenaan dengan posisi sebagai produsen sekaligus konsumen. Potensi kemampuan petani melawan dampak pandemi sangat lemah terutama pada rumah tangga petani kecil (diartikan miskin). Menurunnya aktivitas dan anjloknya harga komoditas akan menekan pendapatan, akan memperlemah ketahanan pangan, kecukupan gizi dan kesehatan. Terlebih bagi petani miskin di kelompok/komunitas yang didominasi keluarga miskin berdampak lebih berat dibanding petani miskin di kelompok masyarakat berpendapatan sedang; yang disebabkan semakin menurunnya kapasitas kesetikawanan kolektif dan lemahnya kemampuan komunitas dalam melakukan local innovate untuk melakukan resiliensi kolektif. Ada program yang dapat diberikan langsung kepada individu, dan juga ada yang bersifat barang publik (public good) yang efektif bila dimanfaatkan bersama, misalnya bantuan alsintan pada kelompok tani. Penanganan dampak pandemi untuk petani dapat dilakukan pada dua level dampak, yakni program-level impact yang terjadi di level individu, dan population-level atau community-level impact.

Untuk itu, dibutuhkan JPS di tengah kesulitan yang juga dihadapi petani kecil di masa Covid-19 sebagai bantuan ekonomi (modal) untuk berusahatani guna menghasilkan pendapatan. JPS disiapkan menyokong dan menopang kaum rentan petani kecil, bukan untuk bangkit kembali, melainkan sebagai pencegahan sebelum mati karena 
tidak mampu memenuhi kebutuhan hidup meskipun membutuhkan intervensi pemerintah melalui pihak terkait, baik di hulu sampai di hilir. JPS di sektor pertanian meliputi berbagai bantuan nonkontribusi untuk meningkatkan kehidupan petani kecil dan individu rentan terdampak karena berbagai keterbatasannya (bahkan dapat diartikan sebagai kemiskinan atau kemelaratan).

Menghadapi pola pandemi Covid19, berbeda dengan tekanan sosial sebelumnya, maka dibutuhkan rancangan dan bentuk program JPS yang juga berbeda. Oleh karena itu, pemberian JPS sebagai bantuan dan dukungan untuk kaum rentan seperti petani kecil dan pelaku pertanian lain beserta keluarga serta masyarakat golongan menengah ke bawah perlu dilakukan secara tepat agar efektif, meskipun belum ada definisi konsep yang tepat dan terpadu, namun keberhasilan efektivitas penyaluran JPS tercermin pada: tidak boleh ada kehilangan nyawa karena tidak makan, harus mampu memberi perlindungan sosial dan secara ekonomi mampu memberikan keselamatan hidup minimum tertentu. Dengan kata lain, untuk mengikis kemiskinan, kelaparan, dan degradasi lingkungan, disarankan hendaknya akselerasi dalam memperkuat pertanian skala kecil dan meningkatkan investasi pertanian agroekologis, memberi perhatian pada: pendapatan dan kesejahteraan petani kecil, kearifan lokal, membalik akses dan kontrol sumber daya (air, tanah, dan modal) dari korporasi ke komunitas lokal, serta memberdayakan dan memperkuat organisasi tani (gabungan hasil download).

\section{PROSPEK JPS SEBAGAI BANTUAN DI MASA PANDEMI COVID-19}

Hal terpenting saat ini bukan hanya mengatasi bencana virus Covid-19 saja, namun upaya akurat untuk membentuk sistem pertahanan dan keamanan nasional di masa pandemi hingga pasca pandemi mendatang. Masyarakat Indonesia sebenarnya sangat beruntung karena memiliki kohesi dan solidaritas sosial yang sangat kuat berdasarkan Pancasila sebagai pandangan hidup bangsa. Hal tersebut semestinya dijadikan momentum untuk menyadari perlunya pemahaman mitigasi bencana sebagai Kesiapsiagaan Bencana di semua aspek terutama dalam pelaksanaan penyaluran JPS. Badan atau lembaga pelaksana penyaluran JPS perlu dikoordinasikan dan diintegrasikan dengan baik dalam satu komando sehingga tidak terjadi kekeliruan dalam 
hal data. Ketidaktersediaan dan lemahnya kohesi dan solidaritas sosial dalam kelembagaan pelaksana penyaluran dan implementasi JPS adalah merupakan kerapuhan yang berperan besar dalam mengganjal implementasi bantuan untuk pengembangan perekonomian pedesaan (terutama petani kecil dan pertanian skala kecil). Jika sistem penyaluran program dibiarkan rapuh, maka program pengembangan teknologi, inovasi dan investasi apapun tidak akan mampu menjadi "mesin penggerak" ekonomi yang tangguh.

Pemerintah menyediakan dana sebesar $\quad \mathrm{Rp}$ 405,1 triliun untuk penanganan wabah Covid-19. Salah satu bentuknya adalah program JPS dengan menyediakan dana Rp 110 trilyun, agar masyarakat dapat memenuhi kebutuhan pokok sehari-hari mereka. Presiden menekankan tiga hal dalam pelaksanaan program JPS, yaitu: tepat sasaran, sesegera mungkin, dan mekanisme penyalurannya seefisien mungkin, yang disertai kesesuaian prosedur, kesesuaian dan kecukupan volume/besaran bantuan JPS tersebut. Ada tujuh bentuk kegiatan dalam program jaring pengaman sosial, yaitu Program Keluarga Harapan (PKH), Padat Karya Tunai (PKT), Bantuan Langsung Tunai (BLT), Kartu Sembako,
Kartu Prakerja, subsidi listrik untuk golongan tertentu, dan bantuan sosial khusus wilayah Jabodetabek (gabungan hasil download).

\section{JPS Bantuan Ekonomi di Masa Pandemi Covid-19}

Program JPS harus dilakukan pemerintah untuk mengurangi tekanan dan dampak pandemi Covid-19. Upaya pemulihan ekonomi nasional (PEN) pasca-Covid-19, anggaran pemerintah mencanangkan Rp641,17 triliun, naik dua kali lipat (Rp318,09 triliun). PEN terbagi empat komponen, yaitu: belanja negara Rp427,46 triliun, pembiayaan Rp133,51 triliun, tambahan belanja Kementerian/Lembaga (K/L) Rp65,1 triliun, dukungan pemerintah daerah (Pemda) Rp15,1 triliun. Dari jumlah anggaran di atas, pemerintah mengalokasikan anggaran untuk dukungan konsumsi baik berupa bantuan sosial (bansos) maupun subsidi sebesar Rp172,1 triliun, yang mencakup perlindungan bagi masyarakat miskin dan rentan melalui Program Keluarga Harapan (PKH), Kartu Sembako, Kartu Prakerja, Diskon Tarif Listrik, Bansos Jabodetabek, Bansos Tunai NonJabodetabek, dan bantuan berupa pangan atau sembako. Pemerintah juga 
menganggarkan Rp34,15 triliun dialokasikan untuk subsidi bunga pada pelaku UMKM. Menteri Keuangan Sri Mulyani menyebutkan dengan prediksi berat, tahun ini pertumbuhan ekonomi hanya tumbuh $2,35 \%$, bisa negatif $-0,4 \%$ dengan skenario sangat berat. Angka kemiskinan diprediksi akan bertambah sekitar 1,1 juta-3,78 juta orang kondisi terburuk. Menurut KADIN jumlah terkena PHK sekitar 6 juta orang, menurut Kemenaker sekitar 1,7 juta orang, menurut BAPPENAS sekitar 2 juta sampai 3,7 juta orang, dan akan munculkan barisan baru kemiskinan (Menteri PPN/Kepala BAPPENAS) (gabungan hasil download).

Terdapat sedikitnya tujuh program pemerintah dalam program JPS. Untuk lebih rincinya, berikut diuraikan rinciannya (gabungan hasil download):

\section{Program Keluarga Harapan} (PKH).. PKH yang biasanya diberi tiga bulan sekali, kini akan diberi sebulan sekali. Nilai manfaat yang diterima masyarakat dinaikkan $25 \%$. Dana anggaran program PKH sebesar Rp37.4 triliun.

2. Kartu Sembako. Ada 20 juta keluarga penerima manfaat kartu ini. Nantinya, jenis bantuan yang sudah menggunakan anggaran Rp43,6 triliun akan dibagikan Rp200 ribu per bulan, selama 12 bulan ke masing-masing penerima.

3. Bantuan Sosial Sembako. Selama April-Juni 2020, total anggaran ini sejumlah Rp3.42 triliun di luar penerima PKH atau kartu sembako. Target sasaran penerima bansos ini hingga 1,3 juta keluarga untuk DKI Jakarta, serta 600 ribu keluarga untuk daerah Bogor, Depok, Tangerang, dan Bekasi.

4. Bantuan Sosial Tunai. Diberikan selama tiga bulan dengan indeks bantuan Rp600 ribu per bulan per keluarga. Kata Menteri Sosial, Juliari P. Batubara, penerima bantuan ini adalah mereka yang belum menenerima bansos PKH, BPNT, atau kartu pra kerja. Para penerima bantuan ini adalah seluruh keluarga di Data Terpadu Kesejahteraan Sosial (DTKS) dan data tambahan dari pemda yang selama ini tak pernah menerima bansos.

5. Bantuan Langsung Tunai. Sama seperti skema bansos tunai, para penerima BLT akan dapat dana Rp600 ribu per bulan per keluarga. Total anggaran bantuan ini Rp21,2 triliun yang menyasar ke 20 juta penerima. 
6. Subsidi Listrik. Bagi pelanggan 450 VA, tarif listrik digratiskan selama tiga bulan ke depan. Jumlahnya mencapai 24 juta pelanggan. Sementara, untuk 900 VA dipangkas biaya pemakaian listriknya hingga 50 persen. Kebijakan ini berlaku bagi 7 juta pelanggan.

7. Kartu Prakerja. Penyaluran kartu ini ditargetkan dimulai sejak April lalu. Kata Presiden, target utama penyaluran kartu ini adalah masyarakat terkena kebijakan pemutusan hubungan kerja, pekerja informal dan pelaku UMKM terdampak Covid-19. Total anggaran untuk program ini Rp20 triliun. Masing-masing penerima dapat Rp600 ribu dan selama 4 bulan.

Peran Kohesi dan Solidaritas Sosial Mendukung Penyaluran JPS Di Masa Covid-19

Pandemi Covid-19 adalah telah merupakan suatu momentum yang sudah menyebabkan berbagai perubahan (tatanan sosial, ekonomi, dan budaya) bagi masyarakat, yang juga telah membuat perubahan besar dan menciptakan ketidakpastian, maupun keselarasan di kehidupan bermasyarakat yang menghasilkan keberlanjutan kohesi dan solidaritas sosial dalam menghadapi suatu kondisi yang sulit dan bermasalah untuk mampu menanganinya secara bersama. Nilai-nilai dan norma-norma yang menghasilkan kohesi dan solidaritas sosial harus secara substantif memasukkan nilai-nilai kejujuran, pemenuhan tugas, dan kesediaan untuk saling menolong.

Diumumkannya kasus pertama positif Covid-19 di beberapa daerah di Indonesia, memunculkan kepanikan hampir di semua kalangan masyarakat. Konten pemberitaannya yang dikonstruksi secara sensasional semakin menonjolkan sisi eksploitatif (layaknya media masa pada umumnya) menimbulkan kepanikan sosial efek moral berupa di tengah masyarakat. Terjadinya aksi sporadis pemborongan masker, hand sanitizer, dan Alat Pelindung Diri (APD) lainnya yang ketersediaannya semakin langka dan cukup mahal. Dengan Peraturan Menteri Kesehatan Nomor 9 Tahun 2020 tanggal 3 April 2020, seluruh kebijakan politik yang diputuskan oleh baik pemerintah pusat maupun daerah harus diiringi dengan tingkat kesadaran hukum masyarakat yang tinggi untuk menaatinya, untuk memutus rantai penyebaran yang merupakan tanggung 
jawab bersama seluruh rakyat, tanpa kecuali.

Meskipun pemerintah pusat dan daerah sudah memberikan banyak bantuan bagi korban Covid-19 bagi terdampak langsung-tidak langsung, yang utama adalah semua elemen masyarakat bahu-membahu turut membantu yang terdampak. Bantuan berupa uang, barang dan yang terkait lainnya dengan rasa bangga dan apresiasi tinggi, mencerminkan kohesi dan solidaritas sosial yang tinggi dan sangat responsif. Perhatian dan menginfokan golongan yang membutuhkan bantuan (JPS) merupakan sikap dan perilaku masyarakat yang dimiliki oleh bangsa Indonesia (hasil kutipan download). Francis Fukuyama mendefinisikan JPS sebagai rangkaian nilai-nilai atau normanorma informal yang dimiliki bersama di antara anggota suatu kelompok yang memungkinkan terjalinnya kerjasama di antara mereka. dengan saling menginformasikan golongan yang membutuhkannya, perilaku yang bisa disebut suatu tindakan altruisme, yaitu semangat untuk membantu dan mementingkan kepentingan orang lain (Fukuyama. 2002; 2014). Lembaga Ilmu Pengetahuan Indonesia (LIPI) menyatakan, penguatan kohesi sosial melalui pemberdayaan solidaritas masyarakat penting dalam pencegahan penyebaran virus corona yang semakin masif ini. Kekuatan kohesi dan solidaritas sosial telah terbukti dalam menghadapi dan mempercepat pemulihan bencana alam dan nonalam.

JPS dapat tersalurkan sebagai bagian bantuan penguatan ekonomi di masa Covid-19 merupakan bantuan ekonomi dalam kehidupan sosial, jaringan, norma, dan kepercayaan serta kehidupan ekonomi yang mendorong tumbuhnya partisipatif dari semua aspek masyarakat yang diharapkan dapat membentuk kohesi sosial secara lebih efektif bertindak bersama untuk mencapai tujuan bersama. Selain itu, nilai-nilai altruisme yang tumbuh dan berkembang selama ini di masyarakat harus di hidupkan kembali yang dapat memperkuat kohesi sosial masyarakat. Kohesi sosial merupakan solidaritas sosial berperan sangat penting dalam menjaga kohesi antarwarga dan menjadi alat kontrol sosial. Pandemi Covid-19 telah membawa berbagai dampak yang luas dan multi dimensi, sehingga mekanisme-mekanisme normal yang biasa dilakukan misalnya mengandalkan mekanisme pasar sulit untuk melakukan recovery. 


\section{PENUTUP}

Pandemi COVID-19 telah membuat perubahan besar dan menciptakan ketidakpastian di kehidupan masyarakat. Keharusan untuk mengisolasi diri dari dunia luar dan ketidakpastian kapan akan berakhirnya pandemi ini mempengaruhi tingkat kekhawatiran masyarakat. Kondisi ini dan kekhawatiran (kesehatan dan ekonomi) diprediksi akan mempengaruhi kesehatan mental (dan sosial) setiap individu. Memelihara kohesi sosial di tengah pandemi Covid19, solidaritas sosial berperan sangat penting dalam menjaga kohesi antarwarga dan menjadi alat kontrol sosial. Selain itu, nilai-nilai altruisme yang tumbuh dan berkembang selama ini di masyarakat harus di hidupkan kembali sebagai solidaritas sosial yang dapat memperkuat kohesi sosial masyarakat (Elizabeth. 2017a).

Menurunnya kapasitas kesetikawanan kolektif dan lemahnya kemampuan komunitas dalam melakukan local innovate untuk melakukan resiliensi kolektif, mengakibatkan semakin beratnya beban petani kecil di masa pandemi Covid-19. Keberhasilan dalam pelaksanaan ketujuh bentuk kegiatan dalam program jaring pengaman sosial, yaitu Program Keluarga Harapan (PKH),
Padat Karya Tunai (PKT), Bantuan Langsung Tunai (BLT), Kartu Sembako, Kartu Prakerja, subsidi listrik untuk golongan tertentu, dan bantuan sosial khusus wilayah Jabodetabek harus didasari tepat sasaran, sesegera mungkin, dan mekanisme penyalurannya seefisien mungkin. Program JPS harus dilakukan pemerintah untuk mengurangi tekanan dan dampak sosial ekonomi pandemi Covid-19. Menghadapi pola pandemi Covid-19 berbeda dengan pola tekanan sosial sebelumnya, maka dibutuhkan rancangan dan bentuk program JPS yang juga berbeda.

Dengan momentum pandemik ini, fikiran, sikap, dan tindakan sekretarian harus dicegah dengan berbagai cara supaya tidak direproduksi secara terusmenerus. Bila solidaritas sosial mampu digerakkan dan diperkuat bukan tidak mungkin JPS untuk lapisan masyarakat sampai ke level bawah di saat menghadapi pandemi Covid-19 dapat diupayakan dengan optimal. berbagai upaya yang dilakukan oleh pemerintah dalam menghadapi pandemi Covid-19 juga secara simultan harus didukung dengan kohesi dan solidaritas sosial dan publik yang di miliki oleh masyarakat itu sendiri. Setiap warga negara juga harus memiliki kesadaran, kepedulian, dan 
kepercayaan baik kepada pemerintah maupun antar masyarakat guna mendukung keberhasilan dalam mengatasi pandemi Covid-19 dengan menumbuhkan basis sosial yang kuat.

\section{KESIMPULAN DAN IMPLIKASI KEBIJAKAN}

- Wabah pandemi Covid-19 harus dipercaya keberadaan dengan tidak terprediksinya jangka waktu untuk pemulihan kenormalan kondisi dan situasi.

- Pertahanan keamanan pangan, kehidupan dan ketahanan sosial membutuhkan perhatian yang lebih serius di masa oleh virus corona SARS-CoV-2 yang serba tidak menentu seperti sekarang ini.

- Pandemi Covid-19 merupakan suatu momentum telah membawa berbagai dampak yang luas dan multi dimensi, dimana mekanisme normal yang mengandalkan mekanisme pasar sulit untuk melakukan recovery.

- Program JPS menyokong dan menopang kehidupan, bukan untuk bangkit kembali, melainkan sebagai pencegahan sebelum terancam kehidupan terutama petani kecil dan masyarakat golongan menengah ke bawah yang rentan karena berbagai keterbatasannya.

- Program JPS harus dilakukan pemerintah untuk mengurangi tekanan dan dampak sosial ekonomi pandemi Covid-19 yang berbeda dengan pola tekanan sosial sebelumnya, sehingga membutuhkan kesiapan yang lebih dalam penanganan penyalurannya.

- Program JPS merupakan keniscayaan yang harus dijalankan pemerintah, meski disertai intervesi yang dalam kelancaran pelaksanaan penyalurannya didukung kohesi dan solidaritas sosial, yang disertai solidaritas publik.

- Perlunya memberdayakan dan menguatkan kohesi dan solidaritas sosial yang sangat penting dalam menjaga kohesi antarwarga dan menjadi alat kontrol social yang disertai nilai-nilai altruisme untuk tumbuh dan berkembang di masyarakat.

\section{DAFTAR PUSTAKA}

Aiyer, S., A. Parker and J. V. Zyl. 1995. The Myth Of Large-Farm Superiority AGR Dissemination Notes. No. 6 (August 1995) http://www-wds.worldbank.org/.....

Altieri, M. A. 1995. Agroecology: The Science of Sustainable Agriculture. Boulder: Westview Press. 
Amaluddin, M. 1987. Kemiskinan dan Polarisasi Sosial: Studi Kasus di Desa Bulugede, Kendal, Jawa Tengah. UI-Press, Jakarta

Badan Pusat Statistik. 2020. Analisis Hasil Survei Dampak Covid-19 Terhadap Pelaku Usaha. BPS. Jakarta.

Badan Pusat Statistik. 2020. Survei Sosial Demografi Dampak Covid-19 2020. BPS. Jakarta

Elizabeth. R. 2019. Peningkatan Dayasaing Tanaman Pangan Melalui Akselerasi Agroindustri Dan Pemberdayaan Kelembagaan Pertanian. Mimbar Agribisnis: Jurnal Pemikiran Masyarakat Ilmiah Berwawasan Agribisnis. Vol 5, No 2 (2019): Juli 2019. Akreditasi Nomor 34/E/KPT/2018 at SINTA 4 (S4) rank. Accreditation is valid from December 10, 2018 to December 10, 2023.2 DOI: http://dx.doi.org/10.25157/ma.v5i2. $\underline{2411}$

Elizabeth. R. 2017. Revitalisasi Industri Produk Olahan Dan Pemberdayaan Lembaga Kemitraan Mendukung Peningkatan Pemasaran, Daya Saing Dan Pensejahteraan Petani Pisang. Journal of Agricultural Scienties. UNES. (Universitas Ekasakti). Padang Sumatera Barat. Volume 2. Issue 1. June 2017. ISSN Cetak: 2528-5556. ISSN Online: 2528-6226.

Elizabeth. R. 2017a. Akselerasi Pemberdayaan Dan Peningkatan Kompetensi Dalam Sistem Produksi Untuk Mengatasi Permasalahan Ekonomi Di Indonesia. Volume 2. Issue 1. June 2017. ISSN Cetak: 2528-5556. ISSN Online: 2528-6226.

Chappell, M.J. and L. A. LaValle. 2011. Food Security and Biodiversity: can we have Both? An
Agroecological Analysis. Agriculture and Human Values, Vol. 28(1): 3-26.

Eg Peter Hazell, January 2005. Is there a Future for Small Farms? Agricultural Economics, Vol. 32, pp93-101. doi:10.1111/ j.01695150.2004.00016.

Fatma Gül Ünal, October 2006. Small Is Beautiful: Evidence of Inverse Size Yield Relationship In Rural Turkey Policy Innovations. http://www.policyinnovations.org/id eas/policy_library/data/01382

Francis Fukuyama, Trust: Kebajikan Sosial dan Penciptaan Kemakmuran, Yogyakarta: Penerbit Qalam, 2002, hal. 36.

Francis Fukuyama, The Great Disruption: Hakikat Manusia dan Rekonstitusi Tatanan Sosial, Yogyakarta: Penerbit Qalam, 2014, hal. 42 dan 24.

Harvest, Fatal (ed).nThe Seven Deadly Myths of Industrial Agriculture: Myth Onea August 22, 2002. http://www.alternet.org/story/ 13900/. "The Seven Deadly Myths of Industrial Agriculture" were Compiled by the editors of Fatal Harvest, which is published by the Foundation for Deep Ecology and distributed by Island Press.

https://www.beritasatu.com/politik/62887 7-penyalahgunaan-bansos-untukkepentingan-politik-marak-terjadi

https://www.merdeka.com/peristiwa/dataterkini-jumlah-korban-virus-coronadi-indonesia.html

https://www.cnnindonesia.com/nasional/2 0200429062046-20-498263/calonepisentrum-corona-baru-semarangsurabaya-dan-makassar

https://nasional.kontan.co.id/news/pengan gguran-akibat-COVID-19-bisamelebihi-hitungan-pemerintah 
https://nasional.kontan.co.id/news/pengan gguran-akibat-COVID-19-bisamelebihi-hitungan-pemerintah

https://finance.detik.com/berita-ekonomibisnis/d-5011381/phk-takterbendung-bahaya-gelombangkemiskinan-baru.

https://ekonomi.bisnis.com/read/2020051 9/9/1242697/anggaran-pemulihanekonomi-nasional-naik-2-kali-lipatuntuk-apa

https://money.kompas.com/read/2020/05/ 19/063600726/anggaranpemulihan-dampak-pandemi-naikjadi-rp-641-17-triliun-inirinciannya?page $=$ all

McKone, C.E. 1990. FAO People's Participation Programme - the First 10 Years: Lessons Learnt and Future Directions. Human Resources Institutions and Agrarian Reform Division, Food and Agriculture Organization of the United Nations, 1990.

Monbiot, G. 2008. Peasant Farmers Offer the Best Chance of Feeding the World. So why do we treat them with Contempt? The Guardian, 10 June 2008.

Mubyarto dan A. Santosa. 2003. Pembangunan Pertanian Berkelanjutan: Kritik terhadap Paradigma Agribisnis. Artikel dalam Majalah Ekonomi Rakyat Th. II No. 3, Mei 2003. (http://www.ekonomirakyat.org/edis i 15/artikel 7.htm., 29 September 2020).

Portes, A. 2006. Institution and Development: A Conceptual Reanalysis [Institusi dan Pembangunan: Sebuah AnalisisUlang Konseptual]. Population and Development Review 32 (2): $233 \mathrm{i}$ 262.

Rosset, P.M. The Multiple Functions and Benefits of Small Farm Agriculture In the Context of
Global Trade Negotiations. By Ph.D. September 1999. Food First/The Institute for Food and Development Policy Oakland, CA USA. http://www.foodfirst.org/ node/246.

Santosa, D.A. 2011. RUU Kedaulatan Petani. Harian Kompas, 8 September 2011.

Santosa, D.A. 2012. Benih Kedaulatan Petani. Harian KOMPAS, 4 Juni 2012

Setiawan, U. Deputi Sekretaris Jenderal Konsorsium Pembaruan Agraria (KPA). 17 April, Hari Perjuangan Petani Sedunia. Copy-right Sinar Harapan 2003. (http://www.terranet.co.id/beritanya. php?id =11639, 21 April 2005).

Syahyuti. 2012. Kelemahan Konsep dan Pendekatan dalam Pengembangan Organisasi Petani: Analisis Kritis terhadap Permentan No. 273 tahun 2007. Majalah Analisis Kebijakan Pertanian Vol 10 No.2 tahun 2012).

Syahyuti. 2012. 35 tahun Berkarya untuk Petani: Sinopsis Penelitian PSEKP periode 1976 i 2010. IAARD Press.

Syahyuti. 2013. Pemahaman Terhadap Petani Kecil Sebagai Landasan Kebijakan Pembangunan Pertanian. Forum Agro Ekonomi. Vol.31 No.1 Juli 2013:15-29. Pusat Sosial Ekonomi dan Kebijakan Pertanian. Bogor. Kementerian Pertanian. Jakarta

Tjondronegoro, S.M.P. 1984. Sosial Organization and Planned Development in Rural Java: A Study of the Organizational Phenomenon in Kecamatan Cibadak, West Java and Kecamatan Kendal, Central Java, Singapore: Oxford University Press.

Tjondronegoro, S.M.P. 1999. Revolusi Hijau dan Perubahan Sosial di 
Pedesaan Jawa. Dalam buku Keping-Keping Sosiologi dari Pedesaan. Jakarta: Direktorat Jenderal Pendidikan Tinggi, Departemen Pen- didikan dan Kebudayaan RI. Hal. 22.

Trijono, L. 1994. Pasca Revolusi Hijau di Pedesaan Jawa Timur (pp. 23-31). Majalah Prisma No. 3, Maret 1994.
Soekartawi. Sebuah Catatan Tentang Definisi Petani Besar Dan Kecil. Lektor Madya pada Fakultas Pertanian Universitas Brawijaya.

World Bank. 2008. World Development Report: Agriculture for Development. 